\title{
Subduction processes in the Meso- Neoarchean Pitangui Greenstone Belt, southeastern Brazil: Insights from lithogeochemistry and trace element modelling
}

PIERO A. B. DE SAMPAIO ${ }^{1}$, ATLAS V CORRÊA NETO ${ }^{1}$ MARIANA BRANDO SOARES ${ }^{2}$, FELIPE E.A. ALVES ${ }^{1}$, GABRIEL M. DA SILVA ${ }^{1}$ AND ANA CLARA VARCA PINHEIRO $^{1}$

${ }^{1}$ Universidade Federal do Rio de Janeiro

${ }^{2}$ Universidade do Estado do Rio de Janeiro

Presenting Author: pierobsampaio@gmail.com

The Pitangui Greenstone Belt (PGB) is a Meso-Neoarchean Greenstone Belt located in the southern São Francisco Craton (SSFC; Brazil). This work is based on whole-rock geochemical analyses of drill core samples of metavolcanic and metasedimentary rocks from the Turmalina gold mine (Jaguar Mining co.) and neighboring deposits in the northwestern PGB. Most of the mafic igneous samples show tholeiitic basaltic and picritic signatures and incompatible element patterns which are typical of Archean non-arc basalts but have strongly subchondritic $\mathrm{Nb} / \mathrm{Ta}$ (average of 10.93) reflecting the tapping of a slightly depleted mantle source. Towards the top of the stratigraphic sequence mafic to intermediate rocks with elevated $\mathrm{Nb}$ contents $(5.83-14.61 \mathrm{ppm}),(\mathrm{Nb} / \mathrm{La})_{\mathrm{PM}}$ between 0.69 and 0.91 and slightly negative to absent $\mathrm{Nb}$ mantle normalized anomalies are observed. These rocks are classified as $\mathrm{Nb}$ enriched basalts and andesites, similar to $\mathrm{Nb}$-enriched mafic lithologies described elsewhere in the Archean as well as in the post-Archean record. These lithotypes indicate that the mantle beneath the PGB was metasomatized by slab-melts, most likely adakitic in nature. Adakites were not directly sampled. However, dacite clasts in metavolcaniclastic rocks with incompatible element patterns similar to the $\mathrm{Nb}$-enriched lithologies hint to a hidden dacitic, possibly adakitic, component in the source. Rocks akin to type III low-Ca boninites [1] were also identified within the PGB. These rocks were generated by melting of a depleted mantle calculated to have undergone $10 \%$ depletion relative to primitive mantle. Metagraywackes show characteristics that indicate derivation mainly from mafic lithologies and were likely formed in an oceanic arc. The information extracted from the rocks in this study allow us to propose an oceanic island arc with associated back-arc setting for the northwestern PGB region. The episodes of mantle depletion and metasomatism, with lithotypes that are known exclusively from arc environments, suggest that plate-tectonic -like processes were active in the Mesoneoarchean SSFC.

[1] Crawford A. J., Falloon T. R. and Green D. H. (1989) Classification, petrogenesis and tectonic setting of boninites. In Boninites and Related Rocks (ed. A. J. Crawford). 